(C) Group of authors, 2021

UDC 617.55+617.55-007.274

DOI - https://doi.org/10.14300/mnnc.2021.16047

ISSN - 2073-8137

\title{
PLATELET-RICH AUTOPLASMA USE AT EARLY STAGES OF WOUND HEALING TO PREVENT PATHOLOGICAL SCAR DEVELOPMENT
}

Vladimirova O. V. 1, 2 , Lavreshin P. M. ${ }^{1}$, Vladimirov V. I. ${ }^{3}$, Grigorova A. N. ${ }^{1}$, Gobedzhishvili V. V. ${ }^{4}$, Dolgalev Al. Al. ${ }^{1}$, Timofeev S. I. ${ }^{5}$, Korablina S. S. ${ }^{1}$

1 Stavropol State Medical University, Russian Federation

${ }^{2}$ City Hospital № 2, Stavropol, Russian Federation

3 Pyatigorsk Interregional Oncological Dispensary, Russian Federation

${ }^{4}$ I. M. Sechenov First Moscow State Medical University (Sechenov University),

Russian Federation

${ }^{5}$ Far Eastern State Medical University, Khabarovsk, Russian Federation

\section{ПРИМЕНЕНИЕ ОБОГАЩЕННОЙ ТРОМБОЦИТАМИ АУТОПААЗМЫ НА РАННИХ СТААИЯХ РАНОЗАЖИВАЕНИЯ ААЯ ПРОФИААКТИКИ ОБРАЗОВАНИЯ ПАТОАОГИЧЕСКОГО РУБЦА}

\author{
О. В. ВАаАимирова ${ }^{1,2}$, П. М. Ааврешин ${ }^{1}$, В. И. ВАаАимиров ${ }^{3}$, А. Н. Григорова ${ }^{1}$, \\ В. В. ГобеАЖишвили ${ }^{4}$, А. А. Аолгалев ${ }^{1}$, С. И. Тимофееев ${ }^{5}$, С. С. Кораблина ${ }^{1}$ \\ 1 Ставропольский госуАарственный МеАицинский университет, \\ Российская ФеАерация \\ 2 ГороАская кАиническая больница № 2, Ставрополь, Российская ФеАерация \\ 3 Пятигорский межрайонный онкологический Аиспансер, Российская ФеАерация \\ 4 Первый Московский госуАарственный меАицинский Университет \\ им. И. М. Сеченова (Сеченовский Университет), Российская ФеАерация \\ ${ }^{5}$ Аальневосточный госУАарственный меАицинский университет, Хабаровск, \\ Российская ФеАерация
}

Pathological excess scar treatment is currently viewed as one of the most urgent issues with no single standard solution. We investigated the effectiveness of platelet-rich autoplasma use to stimulate wound healing. Seventy-six patients were assigned to two equivalent groups: control and main. The dynamics revealed a high efficiency of the plasma autostimulation method, which reduced the time of inpatient treatment, accelerated healing with a decrease in the effects of inflammation in the area of injury, stabilized angiogenesis, fibroplasia, and epithelialization, and, as a consequence, decreased the developmental rate of a pathological scar.

Keywords: pathological scars, keloid, hypertrophic scar, autostimulation, scar diary, platelet-rich plasma, prevention of pathological scar formation, stimulation of healing

Лечение патологических избыточных рубцов на данный момент является одной из актуальных и не имеющей единого пути решения или стандарта проблемой. Было проведено исследование эффективности применения обогащенной тромбоцитами аутоплазмы для стимуляции ранозаживления. Семьдесят шесть пациентов были разделены на две равнозначные группы: контроля и основную. В динамике выявлена высокая эффективность метода аутостимуляции плазмой, позволяющая сократить сроки стационарного лечения, ускорить заживление с уменьшением явлений воспаления в зоне травмы, стабилизацию ангиогенеза, фиброплазии и эпителизации и, как следствие, снизить интенсивность роста патологического рубца.

Ключевые слова: патологические рубцы, келоид, гипертрофический рубец, аутостимуляция, дневник рубца, обогащенная тромбоцитами плазма, профилактика патологического рубцеобразования, стимуляция заживления

For citation: Vladimirova O. V., Lavreshin P. M., Vladimirov V. I., Grigorova A. N., Gobedzhishvili V. V., Dolgalev Al. Al., Timofeev S. I., Korablina S. S. PLATELET-RICH AUTOPLASMA USE AT EARLY STAGES OF WOUND HEALING TO PREVENT PATHOLOGICAL SCAR DEVELOPMENT. Medical News of North Caucasus. 2021;16(2):203-205. DOI - https://doi.org/10.14300/mnnc.2021.16047

Для цитирования: Владимирова О. В., Лаврешин П. М., Владимиров В. И., Григорова А. Н., Гобеджишвили В. В., Долгалев А. А., Тимофеев С. И., Кораблина С. С. ПРИМЕНЕНИЕ ОБОГАЩЕННОЙ ТРОМБОЦИТАМИ АУТОПЛАЗМЫ НА РАННИХ СТАДИЯХ РАНОЗАЖИВЛЕНИЯ ДЛЯ ПРОФИЛАКТИКИ ОБРАЗОВАНИЯ ПАТОЛОГИЧЕСКОГО РУБЦА. МЕДИцинский вестник Северного Кавказа. 2021;16(2):203-205

DOI - https://doi.org/10.14300/mnnc.2021.16047 
$\mathbf{P}$ athological scar prevention and treatment is currently one of the most relevant issues faced by the rehabilitation system following injuries and operations. It is at the junction point of many medical specialties, including dermatology, surgical specialties, rehabilitation medicine, and immunology, because only a detailed study and a thorough understanding of the processes underlying scar tissue development can help control its development, and this frequently involves different specialists $[1,2]$.

The last ten years have witnessed an increase in patient numbers after injuries and operations seeking to treat pathological hypertrophic and keloid scars. This is particularly true for children and patients of a young working age. Statistics from the World Health Organization (WHO) analytical department indicate that over 100 million patients globally undergo surgical interventions annually of various complexity, of whom $4-10 \%$ are likely to develop pathological scars, while $10-15 \%$ of patients suffering from burns experience excessive growth of connective tissue in the injured area.

Rough deforming scars developed due to damaged cover tissues cause physical and psychological discomfort, frequently affecting the quality of life and even resulting in disability. Currently, there is no single standard treatment or prevention for pathological scar development. Consequently, numerous different treatment modalities and drug prescriptions are not always valid regarding the pathogenetic viewpoint. Platelet-rich autoplasma (PRA) application to stimulate tissue regeneration has attracted interest as an effective and safe method in many areas. The relevance of research in this area is the need to assess the effectiveness of using PRA to stimulate wound healing.

This study aims to evaluate the effectiveness of using PRA to treat patients with a high risk for developing pathological scars.

Material and Methods. We observed 76 patients from 2010 to 2019 aged between $16-45$ years, 43 of whom were males and 33 females, with traumatic and postoperative scars. At the beginning of treatment, all the patients had their risk for developing pathological scar evaluated based on medical history data, examination, acetylation type identification, dermatoscopy to detect skin features, the type of pathology or injury, and its localization, as well as based on specific characteristics of the surgical treatment and healing. The study design was approved by the Local Ethics Committee.

The inclusion criteria were a patient age (both sexes) ranging from 16 to 45 years; the nature of the wound (bitten, torn, chopped, second/third degree burns affecting up to $15 \%$ of the body, infected wounds after phlegmon and abscess opening). The non-inclusion criteria were: decompensated diabetes mellitus, hormonal decompensated dysfunctions, chemotherapy and hormone therapy, coagulopathy, intoxication signs confirmed through lab tests, age $<16$ and $>45$ years, pregnancy, lactation, kidney or liver failure.

The patients were assigned by blind randomization to two groups: Group I (main group) included 32 patients, where, apart from standard treatment, wound healing autostimulation was employed in the early stages of wound healing through administering PRA; Group II (control group) included 44 patients who received conventional treatment. The patients of both groups were given surgical assistance, including due primary surgical treatment of wounds, antibacterial therapy following respective indications, and up-to-date dressings.

Patients of Group I, who on Days 2-3 following surgical treatment of the wound displayed no suppuration, received PRA injected at the wound site. PRA was obtained through centrifugation of the patient's own blood taken from a peripheral vein ( $9 \mathrm{ml}$ per tube), with sodium citrate added. Centrifugation was performed at 2500 rpm for 3 minutes, and platelets with a low white blood cell content were extracted from the separated blood. The obtained plasma was not combined with any medications and was used within 5-10 minutes. We used a specifically developed method for injecting plasma from the wound site into a spot of intact skin in portions of $0.1 \mathrm{ml}$ per $0.2-0.3 \mathrm{~cm}$ of needle introduction in length, at $0.5-1 \mathrm{~cm}$ intervals along the entire wound perimeter area involving a retrograde fan fashion. The wound bed was treated based on the PRA method of drip irrigation, while the entire wound surface was covered evenly with plasma.

Starting from when the patient came to seek assistance to their inclusion in the study group, the doctor created a specially developed e-record «wounds-scars" (Certificate 2020661221, official registration of software), which was generated to perform the dynamic evaluation of the treatment effectiveness, further rehabilitation, and followup examination. The patients kept a diary to evaluate the dynamics and introduced the respective data in an individual card in the "Scar Diary» mobile application (Certificate 2019666850, official registration of software). The patients entered into the evaluation scale the data (points) regarding the scar status, attaching a scar photo. The scar progress was monitored, being checked every 2-4 weeks, including by ultrasound and dermatoscopy tests.

The obtained data were processed with the Statistica 10.0 software (Statsoft, USA). The Student's criterion (t) was employed to assess statistically significant differences, while the critical significance level ( $p$ ) was assumed to be $\geq 0.05$.

Results and Discussion. In Group I, wound healing with epithelialization development and tight fixation of the wound edges by connective tissue occurred on average on Day $10 \pm 2$ compared with Day $14 \pm 3$ in Group II. Ultrasound and dermatoscopy examination revealed that 11 (34.4\%) patients in Group I had a high density and mass of the tissue that formed the scar at the damaged region, low scar elasticity, and signs of inflammation, stasis, and hyperemia, which persisted for a lengthy period. In Group II, a similar hypertrophic dense scar growth pattern was observed in 29 (65.9\%) patients.

In Group I, 13 (40.6 \%) patients complained of tension, pressure in the region of scar development, soreness, and hypersensitivity. With respect to Group II, such complaints were reported by $34(89 \%)$ patients. With respect to this difference, the dynamic scale of the scar progress assessment indicated that there was a significant $(p<0.05)$ improvement observed in Group I $(0.2 \pm 0.07$ points) compared with Group II (0.6 \pm 0.21 points).

Given that the patients' own plasma was used, the presented method entailed no allergic or any other immune response that might threaten patient well-being or life.

PRA can improve healing through various growth factors as well as cytokines secreted from platelet $\alpha$-granules. The major cytokines found in platelets include transforming growth factor $\beta$, platelet-derived growth factor, insulin-like growth factor (IGF)-I, 
IGF-II, fibroblast growth factor, epidermal growth factor, vascular endothelial growth factor, and endothelial cell growth factor [2]. These cytokines play an important role in cell proliferation, chemotaxis, differentiation, and angiogenesis. The biologically active platelet factors include serotonin, histamine, dopamine, adenosine, and calcium ions. While these factors are not growth factors, they still play a significant role in stimulating damaged tissue recovery. Platelets, by releasing growth factors, adhesion molecules, and lipids, can regulate migration, proliferation, and the function performed by keratinocytes, fibroblasts, and endothelial cells [3]. PRA can be used in regulating angiogenesis, fibroplasia, and epithelization when treating wounds in the second phase of the healing process. The primary reasons for pathological scar development include long-term wound inflammation, disturbance of the cycle of normal granulation development, and delayed epithelialization related to both of these $[4,5]$.

Conclusions. Analysis of the obtained data clearly indicated a significant effect of PRA use in reducing the risk for scar progression $(p<0.05)$ in patients with a high risk for developing pathological scars at the damaged area. The prevention of skin damage is of great importance in scar development, particularly in cases that feature a risk for pathological scarring.

Informed consent: the study was guided by the ethical principles of the Helsinki Declaration and the Rules for Proper Clinical Practice in the Russian Federation. This study was carried out with an informed consent obtained from each patient, as well as it was approved by the Ethics Committee (Protocol 17 of September 16, 2009).

Disclosures: The authors declare no conflict of interest.

Acknowledgments. The authors express their gratitude to the head of the Department of Immunology, Professor, MD. Shcherbine A.Yu., employees of the Department of Immunology, NMITs DGOI FNKTs them. Dm. Rogachev for help in examining patients and verifying the diagnosis. We thank Mitchell Arico from Edanz (https://www.edanz.com/ac) for editing a draft of this manuscript.

\section{References}

1. Anthonissen M., Daly D., Janssens T., Van den Kerckhove $E$. The effects of conservative treatments on burn scars: A systematic review. Burns. 2016;42(3):508-518. https://doi.org/10.1016/j.burns.2015.12.006

2. Silva I. R., Cunha Tiveron L. C. R., Silva M. V., Peixoto A. B., Carneiro C. A. X. [et al.] In situ cytokine expression and morphometric evaluation of total collagen and collagens type I and type III in keloid scars. Mediators Inflamm. 2017:6573802. https://doi.org/10.1155/2017/6573802

3. Nitayavardhana S., Wanitphakdeedecha R. Janice $N$. Eimpunth S., Manuskiatti W. The efficacy and safety of fractional radiofrequency nanoneedle system in the treat- ment of atrophic acne scars in Asians. J. Cosmet. Dermatol. 2020:19:1636-1641.

https://doi.org/10.1111/jocd.13484

4. Minaev S. V., Vladimirova O. V., Kirgizov I. V., Akselrov M. A., Razin M. P. [et al.] Multicenter study of the effectiveness of antiscar therapy in patients at different age periods. Surgery. Journal them N. I. Pirogov. 2020;(9):5158. https://doi.org/10.17116/hirurgia202009159

5. Barbara R., Nicolo C. B., Carlo Ch. Interplay between keratinocytes and fibroblasts: a systematic review providing a new angle for understanding skin fibrotic disorders. Frontiers in immunology. 2020:11(648):1-20. https://doi.org/10.3389/fimmu.2020.00648

\footnotetext{
About authors:

Vladimirova Oksana Vladimirovna, MD, PhD, Associate Professor, Associate Professor of the Department of general surgery, surgery of the Department of purulent surgery and burns; tel.: +79054133340; e-mail: oxy_8181@mail.ru; https://orcid.org/0000-0002-3011-7408

Lavreshin Peter Mikhailovich, MD, PhD, Professor, Head of General Surgery Department; tel.: +79280075502; e-mail: v_lin@mail.ru

Vladimirov Vladimir Ivanovich, MD, PhD, doctor-surgery, oncologist; tel.: +79624014209; e-mail: vla3788@yandex.ru; https://orcid.org/0000-0002-7375-8950

Grigorova Alina Nikolaevna, PhD, Associate Professor of the Department of pediatric surgery, Assistant of the Department of histology;

tel.: +79633877244; e-mail: alina.mashchenko@mail.ru; https://orcid.org/0000-0001-5020-232X

Dolgalev Alexander Alexandrovich, MD, Professor, Professor of the Department of general practice dentistry and pediatric dentistry;

tel.: +79624404861; e-mail: dolgalev@dolgalev.pro; https://orcid.org/0000-0002-6352-6750

Gobedzhishvili Vakhtang Vladimirovich, PhD, Associate Professor, Associate Professor of the Department of surgery; tel.: 89283060575; e-mail: walker87@list.ru; https://orcid.org/0000-0002-8883-4952

Timofeeev Sergey Ivanovich, PhD, Associate Professor of the Department of surgery; tel.: +79148537178; e-mail: timofeev_si@mail.ru; https://orcid.org/0000-0002-5808-0686

Korablina Sofia Sergeevna, PhD, Assistant of General Surgery Department; tel.: +79624478458; e-mail: Korablinas27@gmail.com; https://orcid.org/0000-0002-5113-2543
} 